\title{
ROBOTIK@, A STRATEGY TO MOTIVATE STUDENTS TO CHOOSE ENGINEERING CAREERS.
}

\author{
ROBOTIK@, \\ ESTRATEGIA PARA MOTIVAR A LOS ESTUDIANTES A ELEGIR CARRERAS DE \\ INGENIERÍA
}

\author{
Natividad Rios N. ${ }^{1}$, Edil Melo J. , ( $\left.{ }^{\star}\right)$ Daissy M. ${ }^{2}$,Payares B. ${ }^{2}$. Alisawer G. Meza L. ${ }^{2}$, \\ Juan D. Hernández ${ }^{3}$. y Silvia Baldiris ${ }^{4}$ \\ Recibido para publicación: 12 de abril de 2018 - Aceptado para publicación: 19 de mayo 2018
}

\begin{abstract}
Educational robotics is a demonstrated didactical strategy that motivates students to consider engineering careers and benefits both their professional development as well as the learning process. This paper shows an experience carried out in the city of Cartagena de Indias (Colombia) that includes training teachers and facilitating them to take into consideration teaching educational robotics in the secondary school curriculum. The teachers' training was based on the use of ROBOTREINO, an OER intended to be an educational resource for teachers that introduces them to the world of Educational Robotics. After the training, teachers were able to offer secondary education students a learning experience called ROBOTIK@ based on the use of mobile robots in the field of physics. The experience shows promising results.
\end{abstract}

KEYWORDS: Educational robotic, STEM areas, teachers' training, engineering careers.

\section{RESUMEN}

La robótica educativa es una estrategia didáctica demostrada que motiva a los estudiantes a considerar carreras de ingeniería y beneficia tanto su desarrollo profesional como el proceso de aprendizaje. Este documento muestra una experiencia llevada a cabo en la ciudad de Cartagena de Indias (Colombia) que incluye capacitar a los maestros y facilitarles que tengan en cuenta la enseñanza de la robótica educativa en el plan de estudios de la escuela secundaria. La capacitación de los maestros se basó en el uso de ROBOTREINO, un REA destinado a ser un recurso educativo para maestros que les introduce en el mundo de la robótica educativa. Después de la capacitación, los maestros pudieron ofrecer a los

\footnotetext{
${ }^{1}$ Mg. Docente, I.E. Reino de Bélgica, Medellín, Colombia

${ }^{2}$ Mg.'s, Docentes, I.E. Soledad Román de Núñez, Cartagena, Colombia. (*) Cra.57 \#30D-47 Escallón Villa, (+57)3008437639, (57) (5) 6928014, profe.daissy@gmail.com

${ }^{3}$ PhD., Docente, Underwater Vision and Robotics Research Centre (CIRS), Universitat de Girona, España.

${ }^{4}$ Ph. D., Docente, Fundación Universitaria Tecnológico Comfenalco, (Cartagena, Colombia) y Universidad Internacional de la Rioja (Logroño, España).
} 
estudiantes de educación secundaria una experiencia de aprendizaje llamada ROBOTIK @ basada en el uso de robots móviles en el campo de la física. La experiencia muestra resultados prometedores.

PALABRAS CLAVES: Robótica educativa, áreas STEM, formación docente, carreras de ingeniería.

\section{INTRODUCTION}

During the last years, Information and Communication Technologies (ICT) have had an important development worldwide. In addition, globalization and the opening of markets through free trade agreements have facilitated a rapid exchange of goods but also of knowledge, allowing developing countries to acquire these technologies and to take advantage of them in order to create new knowledge. Colombia is not an exception to this situation, since it currently has treaties with many countries, such as the United States, blocks of countries such as the European Union or Asian countries, and it actively participates in student and professional exchange programs with all of them. However, this scenario of technological and academic globalization contrasts with a socio-economic problem that worries political and academic authorities. This is the growing deficit of professionals related to engineering areas.

Studies carried out in the country have shown that the shortage of professionals in engineering is directly related to the decrease in the university student population in that area. In addition, Colombia's image as a consumer of technology, rather than a producer, a country where engineers do not have a determining professional role, has been identified as a possible cause; along with it, also the inadequate way to orient the curriculum and its didactical strategies to teach STEM areas, the lack of a correct pre-university counselling at the moment of deciding the professional career; the perception of engineering as highly complicated careers; and finally, the lack of quotas and opportunities in public universities.

This research offers an opportunity to address the problem of the preconceived difficulty of engineering by giving insights to teachers about how to use educational robotics as a didactical strategy in the curriculum. It is useful for promoting in the students the interest and motivation to study engineering, highlighting that several domain areas such as systems engineering, electronics and mechanics are directly involved, but also for considering basic areas such as STEM.

We propose to use Educational Robotics as a strategy to motivate students to choose engineering careers, offering to students the opportunity to use a design graphic programming approach for mobile robots. On the one hand, this should facilitate the study of algorithmic thinking concepts and increase the interest in studying engineering careers, and on the other hand, intervene in the curriculum by challenging the student to solve problems in STEM areas, Physics in this particular case.

Teachers' training is focused on the use of an Open Educational Resources (OER) [1] that facilitates the acquisitions of competences related to the functionality of mobile robots and which can be used in the didactical intervention.

To validate the approach in our study we conducted a qualitative research with 10 students from the Institución Educativa Soledad Roman de Núñez located in Cartagena de Indias (Colombia). Teachers received specific training in the use of the mobile robots and the manner in which these should be used in educational settings. This training was supported in the use of the aforementioned OER. Consequently, teachers modified the curriculum in the Physics course that students normally receive in school, by including the use of the mobile robots as a strategy to acquire some Physics and Maths competences but also programming skills.

The results we got from this experience were promising, students showed more motivation working with the mobile robots, they felt confortable working on teams and sharing their experience about the problems they had to solve and they were also really interested in continuing to work on the topic. Some of them indicated that they are now interested in studying engineering careers.

The second section of the paper presents some related works. The third section describes ROBOTREINO, which is an OER intended for teachers as an educational resource that introduces them to the world of Educational Robotics. The fourth and fifth sections present the validation scenario and the results of its implementation. Finally, section sixth presents the conclusions and future work.

\section{RELATED WORD}

There are many previous educational experiences around the world regarding the use of robotics 
in supporting learning at different levels of education. Reported experiences discuss some advantages of using robotics in educational settings, such as: 1 ) robotics motivates students to choose fields of engineering in their professional development [2] and in general is a motivating tool in the development of a society's technological culture [3]; 2) Robotics reduces costs in teaching science because robotics kits allow emulating design laboratories and constructing robots, which usually is very expensive to have in undergraduate programs at a professional level [4]; the multidisciplinary nature of robotics generates scenarios where problems are solved through teamwork, allowing the development of critical thinking skills, research, collaborative and creative learning, and presentation of ideas; Finally, robotics permits connecting theory and practice through the application of STEM subjects (Science, Technology, Engineering and Mathematics) $[5,6,7]$.

Unfortunately, the educational system in the city of Cartagena de Indias (Colombia) does not consider the use of robots in the curriculum.

This work has to do with one of the very few projects related with robotics that have been implemented in the city with the purpose of giving a successful experience that would motivate the government to consider the benefits of Educational Robotics by including it in the curriculums.

\section{ROBOTREINO, AN OPEN EDUCATIONAL LEARNING RESOURCE}

\subsection{General description}

ROBOTREINO is an OER intended for teachers as an educational resource that introduces them in the world of Educational Robotics.

Educational robotics is a motivating strategy for students that facilitate teachers to approach different STEM (Science, Technology, Engineering, Mathematics) subjects of the curriculum. Robotics helps students develop skills and competences such as innovation, social commitment, autonomy, cohabitation, teamwork, leadership, communication, cognitive, logical-mathematical reasoning, design, creativity, entrepreneurship, among others.

To teachers, the OER facilitates the integration of different areas in the curriculum by using robotics and to students, it introduces them into the fantastic world of robots.

The resource creation process was developed considering the principles of universal design for learning (UDL) [8] with the purpose of meeting the learning needs and preferences of all students, caring about the quality of the content, doing it accessible, using materials and methods that benefit learning and providing the necessary feedback to students.

\subsection{General description}

a. Competence

After the training, teachers were able to strengthen the educational curriculums by including didactical strategies based on the use of educational robotics. This allowed them to strengthen students' relation with science and technology in a fun, dynamic and practical way.

\section{b. Outcomes}

OER activities enabled teachers to achieve the following competencies with students:

- Ability to arm and disarm a robot $100 \%$

- Being proactive and analytical using their creativity to solve challenges

- Being able to innovate and investigate making proper use of tools online

- Being able to acquire programming skills autonomously as well as vocabulary including technical terms

- Combining different kinds of knowledge that allows them to strengthen their performance in different areas of the curriculum

\section{b. Work tools}

During the work with the OER, the teachers used the following tools:

\section{Physical tools}

- $\quad$ Electronics kits

- $\quad$ Educational Robotics kits

- $\quad$ Printed Tutorial for assembling the robot

- $\quad$ Computers

\section{Digital Tools}

- $\quad$ Crocodile Clips Software Simulator

- $\quad$ Software online LucidChart

- CmapTools software

- $\quad$ Software online PowToon

- $\quad$ Electric software box2

- $\quad$ Arduino software

- $\quad$ Scratch software

- $\quad$ Minecraft website

- $\quad$ Virtual Platform V-Rep 


\subsection{Activities}

ROBOTREINO considers two kind of activities for teachers:

- Activities related to using robots with the purpose of giving teachers the opportunity to acquire the skills needed in order to use all functionalities of the tool and its potential uses. The tool used was the Kit provide by Pigmalion [9].

- Activities related with offering teachers didactic methodologies in order to modify the curriculum by using educational robotics.

\section{IMPLEMENTATION SCENARIO}

\subsection{Description}

The evaluation scenario to validate ROBOTREINO was conducted in the Institución Educativa Soledad Roman de Nuñez located in Cartagena de Indias (Colombia). 3 Teachers received specific training in the use of the mobile robots and how to use them in educational settings.

The research design corresponded with a qualitative approach with descriptive scope with the following purposes 1) identify if the learning experience using educational robotic was relevant to the students; 2) identify the students' perception on the topics related to physics learnt in the experience; 3) identify other emerging learning areas by means of the learning experience and finally, 4) identify if the learning experience could impact the decision of the students about choosing engineering careers in their future professional development.

The intervention was carried out with 10 students from the institution using the robots in a specific Physics course. Students were intended to learn Physics concepts including basic programming logic. The time spent in this experience had a duration of 4 hours per week distributed between practical activities and virtual work.

During the course and using the robots the students were able to solve real Physics and Math problems acquiring basic programming abilities such as the use of programming blocks, basic programming cycles, among others.

The work sessions with students were also an opportunity to show students the characteristics of several technological careers, such as system, mechanical or electronic engineers.

Figure 1 shows the training that teacher underwent, while Figure 2 shows the workshops with students
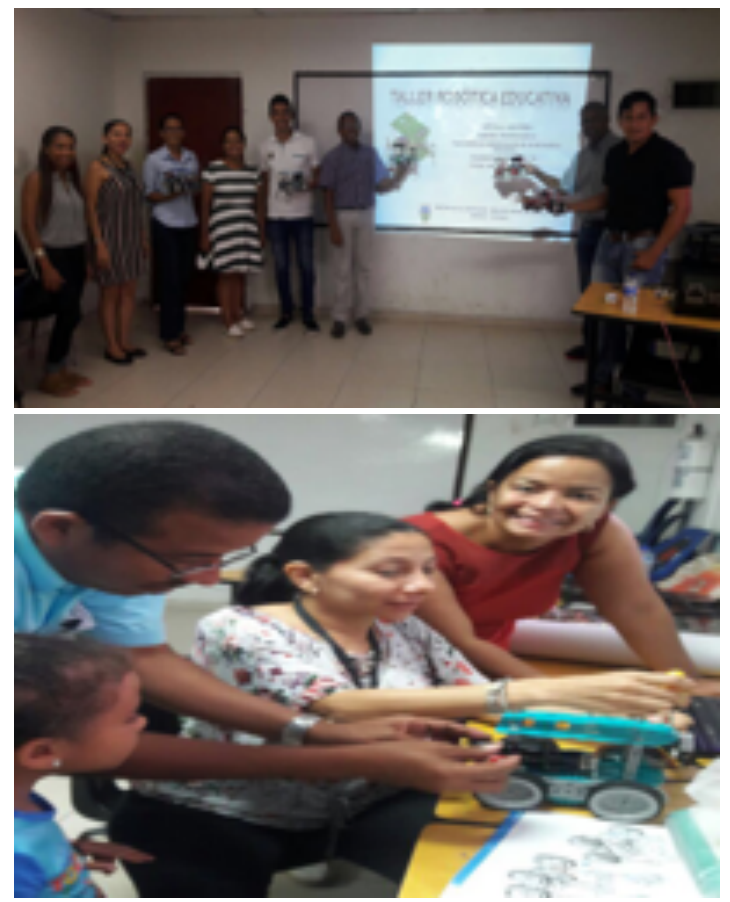

Figure 1. Teachers' training

\subsection{Method and instrument}

Evaluation was based on a semi-structured interview carried out with students. Questions discussed with them were:

a. Based on the experience with the use and manipulation of robots, do you consider that it was a relevant learning experience and did you have fun in Physics classes? Discuss your experience.

b. What topics of the subject of Physics were related to the manipulation, operation and use of robots?

c. In your opinion, apart from Physics, what other subjects or courses could benefit from educational robotics as a learning strategy? What themes would you want to learn using Robotics? d. As a senior in high school and from your experience using Robotics, if you should to choose a career, would be this career related to the use of new technologies?

The interviews were recorded and a content analysis was carried out in order to identify the most important, recurring themes that emerged from each question. 

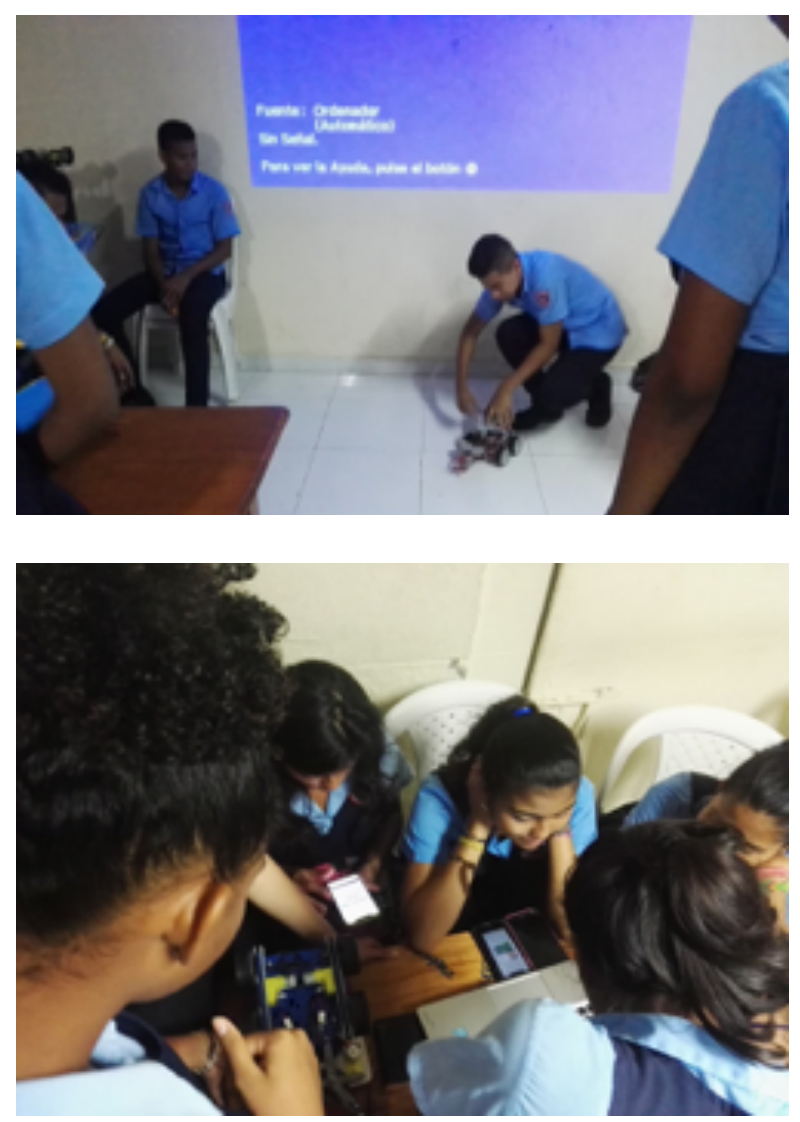

Figure 2. Workshops with students

\section{RESULTS}

Regarding the first question all students agreed that the experience was relevant and that it was a significant learning experience for them. Some ideas that emerged from this question were:

- $\quad$ "The educational experience helps me as an orientation in deciding what career I want to pursue".

- $\quad$ "The experience inspires me to know more about robots and robotics".

- $\quad$ "Physics class became an innovative class for me".

Regarding the second question, the topics related with physics that emerged from the experience were: educational robotics, programming language, sensor knowledge, electrical physics, Arduino, acoustics optics, electrical physics and differential movement.

Regarding the third question, students identified the following courses related with the experience they had in the Physics course that could benefits from Educational Robotics:

- Computing: programming language, algorithm structure, and hardware.

- Mathematics: variables, distance and speed

- Biology: environmental care

- $\quad$ Ethics: respect for copyright

- Language: Reading comprehension of the tutorials

- $\quad$ English

Regarding the fourth question, just one student responded negatively while 9 responded positively, indicating that they will choose a career related to the use of new technologies. The choice the students indicated was influenced by this learning experience.

\section{CONCLUSIONS AND FUTURE WORK}

In this paper we introduced a study on educational robotics that was carried out in order to motivate students from secondary education to consider engineering careers.

Teachers received a training process based on the use of ROBOTREINO, an open educational resource to support the teaching process of robotics in education.

After the learning process, the students were able to arm and disarm a robot accomplishing $100 \%$ of the suggested competence, were proactive and analytical using their creativity to solve challenges in different areas, were able to innovate and investigate making correct use of online tools, acquired new logic and programming skills including technical language vocabulary, and acquired knowledge that allows them to strengthen their performance in different curriculum areas.

The results of the study provide evidence which indicates that this kind of learning experience could motivate students to pursue engineering careers in the future. 


\section{REFERENCES}

[1]. Wiley, D., Bliss, T. J., \& McEwen, M. (2014). Open Educational Resources: A Review of the Literature. In Handbook of Research on Educational Communications and Technology (pp. 781-789).

[2]. Wedeward, K., \& Bruder, S. (2002). Incorporating Robotics into Secondary Education. In 5th Biannual World Automation Congress (pp. 411-416). https://doi. org/10.1109/WAC.2002.1049473

[3]. Dias, M. B., Browning, B., Mills-Tettey, G. A., Amanquah, N., \& El-Moughny, N. (2007). Undergraduate Robotics Education in Technologically Underserved Communities. In IEEE International Conference on Robotics and Automation (pp. 1387-1392). https:// doi.org/doi: 10.1109/ROBOT.2007.363178

[4]. Galvan, S., Botturi, D., Castellani, A., \& Fiorin, P. (2006). Innovative robotics teaching using LEGO sets. In IEEE International Conference on Robotics and Automation (pp. 721-726).

[5]. Gilkes, T., Radix, C., \& Ringis, D. (2014). Across-the-ages: A study of robotics in Caribbean education. In 2014 IEEE Frontiers in Education Conference (FIE) Proceedings (pp. 1-5). https://doi.org/10.1109/ FIE.2014.7044458

[6]. Hrbáček, J., Strach, M., \& Kučera, J. (2013). Teaching robot programming can be a new opportunity for technical subjects of study. In IEEE 11th International Conference on Emerging eLearning Technologies and Applications (ICETA) (pp. 133-137). https:// doi.org/10.1109/ICETA.2013.6674418

[7]. Aroca, R. V., Gomes, R. B., Tavares, D. M., Souza, A. A. S., Burlamaqui, A. M. F., Caurin, G. A. P., \& Goncalves, L. M. G. (2013). Increasing Students' Interest with Low-Cost CellBots. IEEE Transactions on Education, 56(1), 3-8.

[8] Meyer, A., Rose, D. H., \& Gordon, D. (2014). Universal design for learning: Theory and Practice. Wakefield, MA: CAST Professional Publishing.
[6]. Electro. (2017). PYGMALION. Retrieved June 14, 2018, from https://pygmalion.te 